\section{RICYDE. Revista Internacional de Ciencias del Deporte doi: $10.5232 /$ ricyde \\ Rev. Int. cienc. deporte}

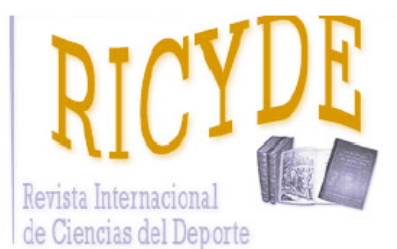

RICYDE. Revista Internacional de Ciencias del Deporte Volume XVI - Year XVI

Pages: $143-152$ - ISSN: $1885-3137$ Issue 60 - April 2020

\title{
Analysis of congested schedule on competition external load in field hockey \\ Análisis de la carga externa de competición en un periodo de congestión en hockey hierba
}

\author{
Blanca Romero-Moraleda ${ }^{1}$, Esther Morencos-Martínez ${ }^{2}$, Lorena Torres-Ronda3 \& David Casamichana ${ }^{4}$
}

\begin{abstract}
1.Department of Physical Education, Sport and Human Movement, Universidad Autónoma de Madrid, Spain. 2.Exercise and Sport Sciences. Faculty of Health Sciences. Universidad Francisco de Vitoria. Madrid, Spain.

3.Institute of Sport, Exercise and Active Living, College of Sport and Exercise Science, Victoria University, Melbourne, VIC, Australia
\end{abstract} 4.Universidad Europea del Atlántico. Santander, Spain.

\begin{abstract}
This study aimed to investigate the variation in players' physical demands profile during a major national men field hockey tournament which consisted of 3 matches on consecutive days. Ten Spanish National League hockey players participated in the study (age: $24.2 \pm 2.6$ years; body mass: $74.2 \pm 5.7 \mathrm{~kg}$; height $176.8 \pm 5.1 \mathrm{~cm}$ ). Participants physical demands were monitored using global positioning system devices (SPI Elite, GPSports). Activity was categorized into total distance $(\mathrm{m})$, relative total distance $(\mathrm{m} \cdot \mathrm{min}-1)$, low speed running (LSR; $<15.0 \mathrm{~km} \cdot \mathrm{h}-1 \mathrm{~m} \cdot \mathrm{min}-1)$; moderate speed running (MSR; 15.1-18.9 km.h-1 m.min-1), high speed running (HSR; $>19 \mathrm{~km} \cdot \mathrm{h}-1 \mathrm{~m} \cdot \mathrm{min}-1$ ), sprinting relative to minute played (SR; $>23.0 \mathrm{~km} \cdot \mathrm{h}-1 \mathrm{~m} \cdot \mathrm{min}-1)$ and number of sprints $(\mathrm{SN} ;>23.0 \mathrm{~km} \cdot \mathrm{h}-1 / \mathrm{n} / \mathrm{min})$. The number of acceleration and deceleration efforts were analyzed using intensity thresholds (low: 1-1.9 m.s-2 n.min-1; moderate: $2-2.9 \mathrm{~m} \cdot \mathrm{s}-2 \mathrm{n} \cdot \mathrm{min}-1$; high: $>3 \mathrm{~m} \cdot \mathrm{s}-2 \mathrm{n} \cdot \mathrm{min}-1$ ). The data were analyzed using one-way repeated measures ANOVA coupled with magnitude-based inferences. Players reduced distance covered at moderate- and high-speed running, sprints relative minute played and the number of moderate accelerations, and moderate and high decelerations per minute played in the third match compared to the first match. The results of this investigation show that intensity activity were the most affected variables with congestion schedule.
\end{abstract}

Keywords: external load, load management, physical demands, tournament, fatigue.

\section{Resumen}

El objetivo del presente estudio fue analizar el perfil de variación de las demandas físicas durante un torneo en hockey hierba, consistente en 3 partidos en días consecutivos. Díez jugadores de la liga nacional de hockey hierba participaron en el estudio (edad: $24.2 \pm 2.6$ años; peso: $74.2 \pm 5.7 \mathrm{~kg}$; altura $176.8 \pm 5.1 \mathrm{~cm}$ ). Las demandas físicas de los participantes en la competición fueron monitorizadas a través de los sistemas de posicionamiento global (SPI Elite, GPSports). La actividad fue categorizada en: distancia total $(m)$, distancia total relativa $(m \cdot m i n-1)$, distancia a baja intensidad (LSR; <15.0 km·h-1 m·min-1); distancia a intensidad moderada (MSR; 15.1-18.9 km·h-1 m.min-1), distancia a alta intensidad (HSR; $>19 \mathrm{~km} \cdot \mathrm{h}-1 \mathrm{~m} \cdot \mathrm{min}-1$ ) y esprín relativo a minuto jugado ( $\mathrm{NS}>23.0 \mathrm{~km} \cdot \mathrm{h}-1 / \mathrm{min}$ $\mathrm{m} \cdot \mathrm{min}-1$ ). El número de aceleraciones y desaceleraciones fue analizado basado en umbrales de intensidad (bajo: 1-1.9 $\mathrm{m} \cdot \mathrm{s}-2 \mathrm{n} \cdot \mathrm{min}-1$; moderado: $2-2.9 \mathrm{~m} \cdot \mathrm{s}-2 \mathrm{n} \cdot \mathrm{min}-1$; alto: $>3 \mathrm{~m} \cdot \mathrm{s}-2 \mathrm{n} \cdot \mathrm{min}-1$ ). Las comparaciones de medias se realizaron mediante medidas repetidas (ANOVA-un factor) junto con inferencias basadas en magnitudes. Los jugadores recorrieron menos distancia a moderada y alta intensidad en el tercer partido respecto al primer partido. También realizaron menos esprines por minuto, así como aceleraciones de intensidad moderada y deceleraciones de moderada y alta intensidad entre dichos partidos. Los resultados de esta investigación sugieren que las actividades de alta intensidad son las variables más afectadas en una situación de alta densidad competitiva.

Palabras clave: carga externa, demanda física, control de la carga, torneo, fatiga.

Correspondencia/correspondence: Blanca Romero-Moraleda

Department of Physical Education, Sport and Human Movement, Universidad Autónoma de Madrid, Spain. Email: blanca.romero@uam.es 
Romero-Moraleda, B.; Morencos-Martínez, E.; Torres-Ronda, L., \& Casamichana, D. (2020). Analysis of congested schedule on competition external load in field hockey. RICYDE. Revista internacional de ciencias del deporte. 60(16), 143-152. https://doi.org/10.5232/ricyde2020.06003

\section{Introduction}

$\mathrm{F}$ ield hockey can be described as a stick-and-ball team sport characterised by variable intensity which repeatedly alternates periods of effort and recovery with a high offensive and defensive technical-tactical emphasis in which players require certain physical qualities (aerobic-anaerobic capacity and power, sprinting, acceleration, deceleration and changes in direction, to cite just a few) in order to perform successfully (Morencos, Casamichana, Torres, Romero-Moraleda, Haro, \& Rodas, 2019). Typically, tournaments in this sport require the players to play in a congested schedule, where they participate on an average of 3 matches in 4 days or 7 matches across a 10-day period (Ihsan, Sahrom, Choo, Chia \& Aziz, 2017; Jennings, Cormack, Coutts, \& Aughey, 2012).

In other outdoor team sports, such as soccer, it has been advised that players may experience neuromuscular fatigue after one single match (Nedelec, McCall, Carling, Legall, Berthoin \& Dupont, 2014) and residual fatigue over the curse of periods of congested schedules (Jones, Greig, Mawéné, Barrow, \& Page, 2018). The causes of fatigue in these situations are multifactorial, including muscle damage (alterations in the levels of markers of muscle damage, inflammatory and immunological markers), alterations in the sense of effort, reduction of glycogen synthesis and dehydration (Twist \& Highton, 2013).

Although not always with such clear results in other study were physical activity, technical performance and injury incidence were unaffected during a prolonged period of fixture congestion (Dellal, Lago-Peñas, Rey, Chamari, \& Orhant, 2015). It should be taken into account also the effect of age in fatigue variables in this kind of congested periods (SanchezSanchez, Sanchez, Hernandez, Ramirez-Campillo, Martínez, \& Nakamura, 2019). Few studies have examined, however, changes in activity profiles over the course of a tournament in elite hockey players. Spencer et al. (2005) determined an increase in walking time and a concomitant decrease in jogging time in subsequent matches when players played 3-in-4 days matches in field hockey. In a study conducted during the World League 2 (field hockey international tournament), the analyzed data showed oscillatory changes across 6 matches throughout the 9-day tournament for physical demands such as total distance, distance running at low-speed and high-speed (Ihsan et al., 2017).

On the other hand, when playing 6-in-9 days matches, field hockey players were able to maintain exercise intensity, without finding changes in players' physical demands as the tournaments progressed (Jennings et al., 2012). Similarly, another study showed that field hockey players under the same congestion schedule context were capable of maintain their physical demands within and across matches (Polglaze, Dawson, Buttfield, \& Peeling, 2017).

When it comes to intra-match analysis, in an international tournament, male field hockey players reported a decrease in total distance in the second half compared to the first half in a match, being the result of a reduced distance covered in the $6.1-11.0 \mathrm{~km} \cdot \mathrm{h}^{-1}$ speed threshold (Lythe \& Kilding, 2011). In contrast, Jennings et al., (2012) have shown a maintenance of the High Speed Running (HSR), either reported as total distance covered or time spent over 15 $\mathrm{km} \cdot \mathrm{h}^{-1}$ across the halves.

Therefore, the aim of this article was to study the variation in players physical demands profile during a major national men field hockey tournament which consisted of 3 matches on consecutive days. 
Romero-Moraleda, B.; Morencos-Martínez, E.; Torres-Ronda, L., \& Casamichana, D. (2020). Analysis of congested schedule on competition external load in field hockey. RICYDE. Revista internacional de ciencias del deporte. 60(16), 143-152. https://doi.org/10.5232/ricyde2020.06003

\section{Participants}

\section{Methods}

Ten male Spanish National League hockey players (backs, midfields and forwards) from the same club participated in the analysis (age: $24.2 \pm 2.6$ years; body mass: $74.2 \pm 5.7 \mathrm{~kg}$; height $176.8 \pm 5.1 \mathrm{~cm})$. The participants played in the Spanish Hockey League First Division, with $6.2 \pm 1.5$ years of experience. The players trained $4.0 \pm 1.5$ times per week, consisted of a regular field hockey-training exposure of 120-minute sessions/week, aside from one official match a week. These data arose from the daily player monitoring in which player activities are routinely measured over the course of the season. Therefore, ethics committee clearance was not required (Winter \& Maughan, 2009). The subjects were informed of the benefits and risks of the investigation prior to signing an institutionally approved informed consent document to participate in the study. The study conformed nevertheless to the recommendations of the Declaration of Helsinki. The technical staff from the investigated sport club supported the study conduction.

\section{Procedures}

Using an observational design, the analyses were conducted during the King's Cup in Spain (season 2015-2016). The tournament was played at the stadium of the organizing club. Match analysis was carried out during three consecutive matches: quarter-final (M1), semi-final (M2) and 3-4th place (M3) with Global Position Systems (GPS). Recovery time between first and second match was of $24 \mathrm{~h}$, and $14 \mathrm{~h}$ between second and third match, resulting in 3 matches in 3 days. Players were only included in the analysis if they participated in all the three matches of the tournament under the normal rotation system of the team (a player was excluded from the study due to injury in the second match). The average time of participation was $82.65 \pm 18.05 \%$ of time played. The characteristics of the matches of the tournament are presented in Table 1.

Table 1. Round and result for the analyzed team during tournament

\begin{tabular}{lccc}
\hline Match & $\begin{array}{c}\text { M1 } \\
\text { Quarter-final }\end{array}$ & $\begin{array}{c}\text { M2 } \\
\text { Semi-final }\end{array}$ & $\begin{array}{c}\text { M3 } \\
\text { 3-4th place }\end{array}$ \\
\hline Duration (min:sec) & $74: 51$ & $66: 23$ & $78: 32$ \\
\hline Final result & $2-1$ & $0-1$ & $5-2$ \\
\hline $\begin{array}{l}\text { Duration refers to the total match. Match 1 (M1); Match 2 (M2); Match 3 } \\
\text { (M3). }\end{array}$
\end{tabular}

Physical demands were recorded using Global Position Systems (GPS) devices operating at $10 \mathrm{~Hz}$ (GPS, SPI Elite, GPSports, Fyshwick, Australia; dimensions, $48 \times 20 \times 87 \mathrm{~mm}$ ). The validity and reliability of the GPS system have been previously reported (CV: $0.3-2.9 \%$ ) (Scott, Scott, \& Kelly, 2016). Each participant wore an individual unit positioned between the scapular planes of the spinal column and secured in place with a harness and was used to wear it usually during the season. These procedures is performed the daily player monitoring in which player activities are routinely measured over the course of the season. Data from each GPS were downloaded to a laptop computer and analyzed using commercially available Team AMS software (v.R1.215.3) and docking station running v2.03B firmware. All matches were of 60 minute-duration ( 4 x 15 minutes-quarters) plus extra-time (time and play is stopped after a penalty corner and goal is awarded). Playing time was calculated using the GPS data and checked using a written record of playing time, taking into account the unlimited interchange allowed in hockey. To limit inter-unit error, each player wore the same unit throughout the tournament. 
Romero-Moraleda, B.; Morencos-Martínez, E.; Torres-Ronda, L., \& Casamichana, D. (2020). Analysis of congested schedule on competition external load in field hockey. RICYDE. Revista internacional de ciencias del deporte. 60(16), 143-152. https://doi.org/10.5232/ricyde2020.06003

\section{Physical demands variables}

Total playing time (TPT, min), percentage of time played (\% TP) and total distance covered (TD; $\mathrm{m}$ ) were recorded during match-play. Time-motion variables were quantified based on distance covered in absolute speed thresholds. These speed thresholds include absolute and relative low speed running (LSR; $<15.0 \mathrm{~km} \cdot \mathrm{h}^{-1}$ and $\mathrm{LSR} \cdot \mathrm{min}^{-1}$ ); moderate speed running (MSR; 15.1-18.9 $\mathrm{km} \cdot \mathrm{h}^{-1}$ and $\mathrm{MSR} / \cdot \mathrm{min}^{-1}$ ), high speed running (HSR; $>19 \mathrm{~km} \cdot \mathrm{h}^{-1}$ and $\mathrm{HSR} / \cdot \mathrm{min}^{-1}$ ) and sprinting $\left(\mathrm{SR}>23.0 \mathrm{~km} \cdot \mathrm{h}^{-1}\right.$ and sprint $\left.\cdot \mathrm{min}^{-1}\right)$. The speed thresholds used have been chosen since they were the ones configured by the manufacturer (Cummins, Orr, O'Connor, \& West, 2013) and are similar to those used by time motion research studies in hockey (Jennings et al., 2012). The number of acceleration and deceleration efforts were analyzed using recently defined thresholds (low - Lacc: $1-1.9 \mathrm{~m} \cdot \mathrm{s}^{-2}$; moderate - Macc: 2-2.9 $\mathrm{m} \cdot \mathrm{s}^{-2}$; high - Hacc: $>3 \mathrm{~m} \cdot \mathrm{s}^{-2}$ ) (Akenhead, Harley, \& Tweddle, 2016). Sprint number (SN $\left.>23.0 \mathrm{~km} \cdot \mathrm{h}^{-1}\right)$ was also recorded. Data were normalized to distance or number of actions per minute $\left(\mathrm{m} \cdot \mathrm{min}^{-1}\right.$ or $\left.\mathrm{n} \cdot \mathrm{min}^{-1}\right)$ to account for differences in TPT (min).

\section{Statistical Analyses}

Data analysis was conducted using the statistical software package SPSS v.23 (SPSS Inc., Chicago, IL, USA). Descriptive data is presented as mean \pm SD. The differences among matches were analyzed using one-way repeated-measures analysis of variance (ANOVA). The statistical threshold was set at $p \leq 0.05$. Additionally, effect sizes (ES) were also calculated in all pairwise comparisons to allow a magnitude-based inference approach. Specifically, the effect-size statistic $\pm 90 \%$ confidence interval (CI) was used on log-transformed data to reduce bias due to non-uniformity of error. Qualitative descriptors were used to describe the likelihood that the rue magnitude of the effect is substantial according to the following schema: $<0.5 \%$, most unlikely; $0.5-5 \%$, very unlikely; $5-25 \%$, unlikely; $25-75 \%$, possibly; 75-95\%, likely; $95-99.5 \%$, very likely; $>99.5 \%$, most likely (Hopkins, Marshall, Batterham, \& Hanin, 2009). All calculations were completed using a predesigned spreadsheet obtained from https://sportscience.sportsci.org/ (Hopkins, Marshall, Batterham, \& Hanin, 2009; Hopkins, 2006).

\section{Results}

Changes of physical demands variables across the tournament are shown in Table 2. Overall, the ANOVA revealed no statistically significant differences across the tournament in physical demands $(p>0.05)$. During M1 players covered higher distance than M3 [ES $=-0.64(-1.43-$ $0.15)$, likely]. LSR $\cdot \mathrm{min}^{-1}$ presented also higher values in M1 than M3 [ES $=-0.67(-1.46-0.11)$, likely]. HSR also was greater in M1 than in M2 and M3 [ES $=-0.65(-1.41-0.11)$ and $-1.2(-$ 1.98- -0.54), likely and very likely, respectively]. Likewise, M3 revealed lower values for SN than in M1 [ES $=-0.96(-1.73-0.2)$ and M2 (ES= -0.58 (-1.34- -0.18), likely]. 
Romero-Moraleda, B.; Morencos-Martínez, E.; Torres-Ronda, L., \& Casamichana, D. (2020). Analysis of congested schedule on competition external load in field hockey. RICYDE. Revista internacional de ciencias del deporte. 60(16), 143-152. https://doi.org/10.5232/ricyde2020.06003

Table 2. Changes in physical demands variables over 3 consecutive matches

\section{Variable}

Difference in percentage $(\% \pm 90 \% \mathrm{CL})$

Uncertainty in the true differences

\begin{tabular}{|c|c|c|c|c|c|c|c|}
\hline & & M1 & M2 & M3 & M1 vs M2 & M2 vs M3 & M1 vs M3 \\
\hline Min played & $60.20 \pm$ & 15.61 & $55.76 \pm 13.77$ & $67.36 \pm 10.65$ & $\begin{array}{c}0.04 \pm 0.53 \\
\text { unclear }\end{array}$ & $\begin{array}{c}0.23 \pm 0.47 \\
\text { unclear }\end{array}$ & $\begin{array}{c}-0.01 \pm 0.20 \\
\text { unclear }\end{array}$ \\
\hline Percentage min played (\%) & $82.65 \pm$ & 18.05 & $84.70 \pm 20.90$ & $86.00 \pm 13.59$ & $\begin{array}{c}0.06 \pm 0.51 \\
\text { unclear }\end{array}$ & $\begin{array}{c}0.04 \pm 0.40 \\
\text { unclear }\end{array}$ & $\begin{array}{r}0.00 \pm 0.27 \\
\text { unclear }\end{array}$ \\
\hline Total distance $(\mathrm{m})$ & $7311 \pm$ & 876 & $6845 \pm 1627$ & $7077 \pm 921$ & $\begin{array}{c}-0.06 \pm 0.31 \\
\text { unclear }\end{array}$ & $\begin{array}{c}0.09 \pm 0.50 \\
\text { unclear }\end{array}$ & $\begin{array}{r}-0.10 \pm 0.15 \\
\text { unclear }\end{array}$ \\
\hline $\operatorname{MSR}(\mathrm{m})$ & $923.58 \pm$ & 259.70 & $854.20 \pm 339.17$ & $799.01 \pm 161.32$ & $\begin{array}{c}-0.04 \pm 0.47 \\
\text { unclear }\end{array}$ & $\begin{array}{c}0.13 \pm 0.59 \\
\text { unclear }\end{array}$ & $\begin{array}{c}-0.12 \pm 0.28 \\
\text { likely }\end{array}$ \\
\hline $\operatorname{HSR}(\mathrm{m})$ & $569.23 \pm$ & 210.10 & $444.36 \pm 203.16$ & $367.11 \pm 122.78$ & $\begin{array}{c}-0.14 \pm 0.49 \\
\text { likely }\end{array}$ & $\begin{array}{c}0.18 \pm 1.14 \\
\text { unclear }\end{array}$ & $\begin{array}{r}-0.26 \pm 0.37 \\
\text { very likely }\end{array}$ \\
\hline Total distance $\left(\mathrm{m} \cdot \mathrm{min}^{-1}\right)$ & $107.27 \pm$ & 41.82 & $123.91 \pm 17.54$ & $105.92 \pm 10.51$ & $\begin{array}{c}0.06 \pm 0.21 \\
\text { unclear }\end{array}$ & $\begin{array}{c}-0.11 \pm 0.15 \\
\text { likely }\end{array}$ & $\begin{array}{r}-0.07 \pm 0.14 \\
\text { unclear }\end{array}$ \\
\hline $\begin{array}{l}\mathrm{LSR} \cdot \mathrm{min}^{-1} \\
\left(\mathrm{~m} \cdot \mathrm{min}^{-1}\right)\end{array}$ & $93.68 \pm$ & 8.99 & $99.85 \pm 10.94$ & $88.10 \pm 7.57 \#$ & $\begin{array}{c}0.07 \pm 0.14 \\
\text { likely }\end{array}$ & $\begin{array}{c}-0.11 \pm 0.10 \\
\text { very likely }\end{array}$ & $\begin{array}{c}-0.05 \pm 0.11 \\
\text { likely }\end{array}$ \\
\hline $\begin{array}{l}\mathrm{MSR} \cdot \min ^{-1} \\
\left(\mathrm{~m} \cdot \mathrm{min}^{-1}\right)\end{array}$ & $13.96 \pm$ & 7.51 & $16.03 \pm 6.57$ & $12.19 \pm 3.47$ & $\begin{array}{c}0.16 \pm 0.61 \\
\text { unclear }\end{array}$ & $\begin{array}{c}-0.03 \pm 0.43 \\
\text { unclear }\end{array}$ & $\begin{array}{c}-0.07 \pm 0.36 \\
\text { unclear }\end{array}$ \\
\hline $\begin{array}{l}\mathrm{HSR} \cdot \mathrm{min}^{-1} \\
\left(\mathrm{~m} \cdot \mathrm{min}^{-1}\right)\end{array}$ & $9.99 \pm$ & 5.94 & $8.08 \pm 3.22$ & $5.62 \pm 2.13$ & $\begin{array}{c}0.07 \pm 0.67 \\
\text { unclear }\end{array}$ & $\begin{array}{c}-0.04 \pm 0.62 \\
\text { unclear }\end{array}$ & $\begin{array}{c}-0.21 \pm 0.42 \\
\text { likely }\end{array}$ \\
\hline $\begin{array}{l}\text { SN } \\
\left(n \cdot \min ^{-1}\right)\end{array}$ & $0.87 \pm$ & 0.24 & $0.91 \pm 0.19$ & $0.74 \pm 0.18$ & $\begin{array}{c}0.14 \pm 0.47 \\
\text { unclear }\end{array}$ & $\begin{array}{c}-0.17 \pm 0.15 \\
\text { likely }\end{array}$ & $\begin{array}{c}-0.09 \pm 0.31 \\
\text { likely }\end{array}$ \\
\hline
\end{tabular}

Date are presented mean \pm standard deviation (SD) and difference in percentage $((\% \pm 90 \%$ Confident limits)). *indicates significant difference with match 1 (M1), \# indicates significant differences with match $2(\mathrm{M} 2)$. Match $3(\mathrm{M} 3)$; Minutes (min). Low speed running $\left(\mathrm{LSR}<15 \mathrm{~km} \cdot \mathrm{h}^{-1}\right)$; Moderate speed running (MSR: $15.1-18.9 \mathrm{~km} \cdot \mathrm{h}^{-1}$; High speed running $\left(\mathrm{HSR}>19 \mathrm{~km} \cdot \mathrm{h}^{-1} ;\right.$ Sprint number per min played $\left(\mathrm{SN}>23 \mathrm{~km} \cdot \mathrm{h}^{-1}\right)$ 
Romero-Moraleda, B.; Morencos-Martínez, E.; Torres-Ronda, L., \& Casamichana, D. (2020). Analysis of congested schedule on competition external load in field hockey. RICYDE. Revista internacional de ciencias del deporte. 60(16), 143-152. https://doi.org/10.5232/ricyde2020.06003

Table 3 presents the comparisons of the number of accelerations and decelerations in three different thresholds. M2 showed likely (vs M1) and very likely (vs M3) higher values for moderate accelerations $\mathrm{n} \cdot \mathrm{min}^{-1}(\mathrm{ES}=1.01(0.26-1.76)$ and $0.82(-1.61--0.02)$ and moderate decelerations $\mathrm{n} \cdot \mathrm{min}^{-1}$ vs M1 $(\mathrm{ES}=1.01(0.27-1.76)$ and $-1.14(-1.92--0.35)$ vs M3. High decelerations $\cdot \mathrm{min}^{-1}$ were lower in $\mathrm{M} 3$ than $\mathrm{M} 2$ and $\mathrm{M} 1$, respectively $(\mathrm{ES}=-1.02(1.79-0.26$; likely) and -0.58 (-1.34- -0.18 ; very likely). For the remaining variables, the differences were rated as unclear.

Table 3. Differences between matches for acceleration and deceleration variables during tournament

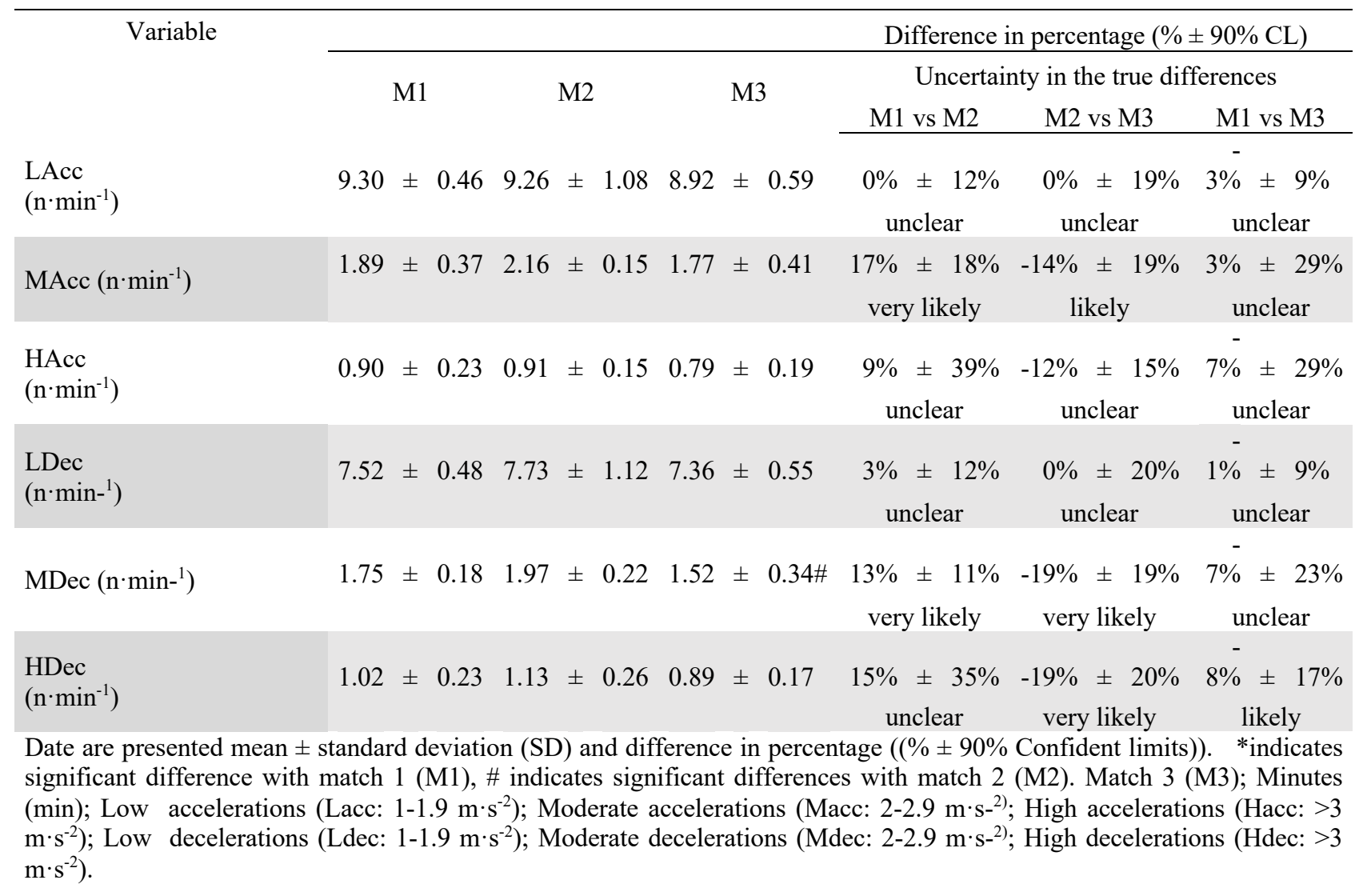

\section{Discussion}

The aim of this study was to analyze the variation in players physical demands profile during a major national men field hockey tournament consisted of 3 matches on consecutive days. The main findings were that players reduced distance covered at MSR and HSR, SN (count $\left.\cdot \mathrm{min}^{-1}\right)$, the number of Macc, and Mdec and Hdec $\left(\mathrm{n} \cdot \mathrm{min}^{-1}\right)$. The main differences were found in the third game compared with the previous two games, specifically for HSR, SN, the number of decelerations (at both moderate and high intensity). To authors' knowledge, the current study is one of the first to observe these changes in male field hockey players during congested fixture tournament. However, other variables such as the total distance (m), LSR $(\mathrm{m})$, MSR $\cdot \mathrm{min}^{-1}$, the number of Lacc, and Ldec and Hacc $\left(\mathrm{n} \cdot \mathrm{min}^{-1}\right)$ have not shown differences between the matches studied.

Several studies consider that the reduction in distance or intensity throughout the course of consecutive matches could be due to fatigue (MacLeod, Bussell, \& Sunderland, 2007; Spencer et al., 2005; Waldron \& Highton, 2014). We have observed a decrease in physical activity in the second and third match in comparison with the first match, which suggest an objective effect of residual fatigue (Spencer et al., 2005). Jennings et al. (2012) analyzed the 
Romero-Moraleda, B.; Morencos-Martínez, E.; Torres-Ronda, L., \& Casamichana, D. (2020). Analysis of congested schedule on competition external load in field hockey. RICYDE. Revista internacional de ciencias del deporte. 60(16), 143-152. https://doi.org/10.5232/ricyde2020.06003

exercise intensity on six matches within a period of nine days during an international competition suggesting that the activity profiles were not influenced by the short recovery between matches (Jennings et al., 2012). In elite level, the unlimited substitution rule and performance level of the squad allows a high rotational strategy during each match, which could potentially explain the ability to maintain high-intensity efforts during the tournament (Linke \& Lames, 2016). In the current study, M1 showed a $14 \pm 49$ and $26 \pm 37 \%$ greatest distance at HSR than M2 and M3, however, the distance relative per minute and moderate accelerations and deceleration per minute were higher in M2 than M1 and M3. Whilst some form of fatigue is likely to occur during a congested period where pacing strategies are developed on behalf of the player (Waldron \& Highton, 2014), might be taken into account other reasons such as the scoreboard across the match and the relevance of it. M1 and M3 were won; given that winning is a comfortable status for a team, it is possible that opposition players assumed a ball contention strategy, keeping the match at slower pace (Andrzejewski, Konefał, Chmura, Kowalczuk, \& Chmura, 2016).

Regarding the possible sensitivity of the variables studied to detect fatigue states, it should be noted that the greatest differences between matches were found in the values of acceleration and deceleration at moderate and high intensity per minute. It seems therefore, that these variables could be more sensitive to detect possible (neuromuscular) fatigue with respect to the traditional variables related to the displacements in different speed ranges (Akenhead et al., 2013; Aughey, 2011). However, we want to stress again that the complexity of team sports performance, and the fact that many factors can influence physical demands, might affect the physical outputs, not being only due to fatigue. Self-regulation or 'pacing' of physical efforts has been suggested as a mechanism of the player to modulate the intensity of the match (Carling, Espié, Le Gall, Bloomfield, \& Jullien, 2010), with the impossibility through GPS data to know if this decrease in activity is related to states of fatigue or not (Bradley \& Noakes, 2013). Moreover, in this study we did not analyze using an individual relative threshold based on their acceleration capacity at different initial speeds, allowing to distinguish better the intensity and to not under or overestimate the demands (MartínezCabrera, Núñez-Sánchez, Losada, Otero-Esquina, Sánchez \& De, Hoyo, 2018).

One contextual variable to consider is the quality of the opposition. Vinson et al. (2018) recently observed that domestic women's field hockey players covered a significantly greater total distance when competing against opponents from top three teams compared to middle three teams (Vinson et al., 2018). In the current study, it can be observed in M2 a greater relative distance per minute, accelerations and decelerations than M1 and M3. This could be due to high level of the opponent and/or the score. This was the one match lost (0-1) and it could be determinant in the physical activity demand. Previous studies in team sports investigated the score-line on physical demands, with more high-intensity activity displayed when losing than they were winning (Almeida, Ferreira, \& Volossovitch, 2014; Sanchez, Hernández, Carretero, \& Sanchez-Sanchez, 2019). It can be interpreted that the results of our study suggest that players could be accumulating fatigue and sometimes engaging in pacing strategies. However, further research to explore this more specifically and with a more appropriate methodology is needed.

The results of this study try to provide new information for coaches and scientists of elite field hockey. Field hockey players experience distinguishable performance fluctuations, we suggest that physical performance data from field hockey should be interpreted in the context of the underlying substitution strategies. Moreover, coaching staff should ensure careful management of players' playing time and recovery, especially in this kind of congested competitions. 
Romero-Moraleda, B.; Morencos-Martínez, E.; Torres-Ronda, L., \& Casamichana, D. (2020). Analysis of congested schedule on competition external load in field hockey. RICYDE. Revista internacional de ciencias del deporte. 60(16), 143-152. https://doi.org/10.5232/ricyde2020.06003

This study is not without limitations, many of which are related to collecting data from professional athletes in their normal competitive environment. Similarly, to many studies examining team sports, we present a data from a tournament that represents a case study of one male hockey team. While we report measurements of running demands, we did not assess the biochemical and objective muscular measurements to quantify fatigue. In addition, the use of other indicators obtained by relating variables, such as the Player Load per meter (Barrett et al., 2016), could provide information on the possible biomechanical changes of the athletes in the different matches. Moreover, results could be determined by the differences in the recovery hours in-between matches, which is a factor of the competition calendar. How each opponent performed is also likely have influenced the results observed in this study, as well as other variables such as humidity or hydration status. Again, access to the opponent's data was not possible and cannot be accounted for in our interpretations.

\section{Conclusions}

In conclusion, these data show that players reduced distance covered at MSR and HSR, SR and the number of Macc, and Mdec and Hdec per minute played in the M3 compared to M1. Even though that not all the variables changed through the tournament in the same way due to several complex aspects previously discussed, it seems that those more related to high intensity are the ones more sensitive to reflect accumulated fatigue.

\section{References}

Akenhead, R.; Harley, J., \& Tweddle, S. (2016). Examining the external training load of an English Premier League football team with special reference to acceleration. Journal of Strength and Conditioning Research/National Strength \& Conditioning Association, 30(9), 2424-2432.

https://doi.org/10.1519/JSC.0000000000001343

Akenhead, R.; Hayes, P. R.; Thompson, K. G., \& French, D. (2013). Diminutions of acceleration and deceleration output during professional football match play. Journal of Science and Medicine in Sport, 16(6), 556-561.

https://doi.org/10.1016/j.jsams.2012.12.005

Almeida, C. H.; Ferreira, A. P., \& Volossovitch, A. (2014). Effects of match location, match status and quality of opposition on regaining possession in UEFA champions league. Journal of Human Kinetics, 41(1), 203-214.

https://doi.org/10.2478/hukin-2014-0048

Andrzejewski, M., Konefał, M., Chmura, P., Kowalczuk, E., \& Chmura, J. (2016). Match outcome and distances covered at various speeds in match play by elite German soccer players. International Journal of Performance Analysis in Sport, 16(3), 817828. https://doi.org/10.1080/24748668.2016.11868930

Aughey, R. J. (2011). Increased high-intensity activity in elite Australian football finals matches. International Journal of Sports Physiology and Performance, 6(3), 367-379. https://doi.org/10.1123/ijspp.6.3.367

Barrett, S.; Midgley, A.; Reeves, M.; Joel, T.; Franklin, E.; Heyworth, R., \& Lovell, R. (2016). The within-match patterns of locomotor efficiency during professional soccer match play: Implications for injury risk? Journal of Science and Medicine in Sport, 19(10), 810-5.

https://doi.org/10.1016/j.jsams.2015.12.514

Bradley, P. S., \& Noakes, T. D. (2013). Match running performance fluctuations in elite soccer: indicative of fatigue, pacing or situational influences? Journal of Sports Sciences, 31(15), 1627-1638.

https://doi.org/10.1080/02640414.2013.796062 
Romero-Moraleda, B.; Morencos-Martínez, E.; Torres-Ronda, L., \& Casamichana, D. (2020). Analysis of congested schedule on competition external load in field hockey. RICYDE. Revista internacional de ciencias del deporte. 60(16), 143-152. https://doi.org/10.5232/ricyde2020.06003

Carling, C.; Espié, V.; Le Gall, F.; Bloomfield, J., \& Jullien, H. (2010). Work-rate of substitutes in elite soccer: A preliminary study. Journal of Science and Medicine in Sport, 13(2), 253-255.

https://doi.org/10.1016/j.jsams.2009.02.012

Cummins, C.; Orr, R.; O'Connor, H., \& West, C. (2013). Global positioning systems (GPS) and microtechnology sensors in team sports: a systematic review. Sports Medicine, 43(10), 1025-1042. https://doi.org/10.1007/s40279-013-0069-2

Dellal, A.; Lago-Peñas, C.; Rey, E.; Chamari, K., \& Orhant, E. (2015). The effects of a congested fixture period on physical performance, technical activity and injury rate during matches in a professional soccer team. British Journal of Sports Medicine, 49(6), 390-394. https://doi.org/10.1136/bjsports-2012-091290

Hopkins W.G. (2006) Spreadsheets for analysis of controlled trials, with adjustment for a subject characteristic. Sportsci, 10:46-50.

Hopkins, W. G.; Marshall, S. W.; Batterham, A. M., \& Hanin, J. (2009). Progressive statistics for studies in sports medicine and exercise science. Medicine and Science in Sports and Exercise, 41(1), 3-13.

https://doi.org/10.1249/MSS.0b013e31818cb278

Ihsan, M.; Tan, F.; Sahrom, S.; Choo, H. C.; Chia, M., \& Aziz, A. R. (2017). Pre-game perceived wellness highly associates with match running performances during an international field hockey tournament. European Journal of Sport Science, 17(5), 593602.

https://doi.org/10.1080/17461391.2017.1301559

Jennings, D.; Cormack, S. J.; Coutts, A. J., \& Aughey, R. J. (2012). GPS analysis of an international field hockey tournament. International Journal of Sports Physiology and Performance, 7(3), 224-231.

https://doi.org/10.1123/ijspp.7.3.224

Jennings, D. H.; Cormack, S. J.; Coutts, A. J., \& Aughey, R. J. (2012). International field hockey players perform more high-speed running than national-level counterparts. The Journal of Strength \& Conditioning Research, 26(4), 947-952. https://doi.org/10.1519/JSC.0b013e31822e591300124278-201204000-00009 [pii]

Jones, R.; Greig, M.; Mawéné, Y.; Barrow, J., \& Page, R. M. (2019). The influence of short-term fixture congestion on position specific match running performance and external loading patterns in English professional soccer. Journal of Sports Sciences, $37(12), 1338-1346$.

https://doi.org/10.1080/02640414.2018.1558563

Linke, D., \& Lames, M. (2016). Substitutions in elite male field hockey-a case study. International Journal of Performance Analysis in Sport, 16(3), 924-934. https://doi.org/10.1080/24748668.2016.11868939

Lythe, J., \& Kilding, A. E. (2011). Physical demands and physiological responses during elite field hockey. International Journal of Sports Medicine, 32(07), 523-528. https://doi.org/10.1055/s-0031-1273710

MacLeod, H.; Bussell, C., \& Sunderland, C. (2007). Time-motion analysis of elite women's field hockey, with particular reference to maximum intensity movement patterns. International Journal of Performance Analysis in Sport, 7(2), 1-12. https://doi.org/10.1080/24748668.2007.11868392

Martínez-Cabrera, F. I.; Núñez-Sánchez, F. J.; Losada, J.; Otero-Esquina, C.; Sánchez, H., \& De, M. H. (2018). Use of Individual Relative Thresholds to Assess Acceleration in Young Soccer Players According to Initial Speed. The Journal of Strength \& Conditioning Research.

https://doi.org/10.1519/JSC.0000000000002902 [Epub ahead of print] 
Romero-Moraleda, B.; Morencos-Martínez, E.; Torres-Ronda, L., \& Casamichana, D. (2020). Analysis of congested schedule on competition external load in field hockey. RICYDE. Revista internacional de ciencias del deporte. 60(16), 143-152. https://doi.org/10.5232/ricyde2020.06003

Morencos, E., Casamichana, D., Torres, L., Romero-Moraleda, B., Haro, X., \& Rodas, G. (2019). Kinematic demands of international competition in women's field hockey. Apunts. Educació Física i Esports, (137), 56-70. http://dx.doi.org/10.5672/apunts.2014-0983.cat.(2019/3).137.05

Nedelec, M.; McCall, A.; Carling, C.; Legall, F.; Berthoin, S., \& Dupont, G. (2014). The Influence of Soccer Playing Actions on the Recovery Kinetics After a Soccer Match. The Journal of Strength \& Conditioning Research, 28(6), 1517-23.

Polglaze, T.; Dawson, B.; Buttfield, A., \& Peeling, P. (2017). Metabolic power and energy expenditure in an international men's hockey tournament. Journal of Sports Sciences, $36(2), 140-148$.

https://doi.org/10.1080/02640414.2017.1287933

Sánchez, M., Hernández, D., Carretero, M., \& Sánchez-Sánchez, J. (2019). Efecto del nivel de oposición sobre el rendimiento físico y el comportamiento técnico-táctico de futbolistas jóvenes. Apunts Educación Física y Deportes, 137, 71-84.

https://doi.org/10.1519/JSC.0000000000000293

Sánchez-Sánchez, J.; Sánchez, M.; Hernández, D.; Ramirez-Campillo, R.; Martínez, C., \& Nakamura, F. Y. (2019). Fatigue In U12 Soccer-7 Players During Repeated One-Day Tournament Games - A Pilot Study. Journal of Strength and Conditioning Research, 33(11), 3092-3097. https://doi.org/10.1519/JSC.0000000000002141

Scott, M. U.; Scott, T. J.; \& Kelly, V. G. (2016). The validity and reliability of global positioning systems in team sport: a brief review. The Journal of Strength \& Conditioning Research, 30(5), 1470-1490.

https://doi.org/10.1519/JSC.0000000000001221

Spencer, M.; Rechichi, C.; Lawrence, S.; Dawson, B.; Bishop, D., \& Goodman, C. (2005). Time-motion analysis of elite field hockey during several games in succession: a tournament scenario. Journal of Science and Medicine in Sport, 8(4), 382-391. https://doi.org/10.1016/S1440-2440(05)80053-2

Twist, C., \& Highton, J. (2013). Monitoring fatigue and recovery in rugby league players. International Journal of Sports Physiology and Performance,8, 467-474. https://doi.org/10.1123/ijspp.8.5.467

Vinson, D.; Gerrett, N., \& James, D. V. B. (2018). Influences of playing position and quality of opposition on standardized relative distance covered in domestic women's field hockey: Implications for coaches. The Journal of Strength \& Conditioning Research, 32(6),1770-1777. https://doi.org/10.1519/JSC.0000000000002049

Waldron, M., \& Highton, J. (2014). Fatigue and pacing in high-intensity intermittent team sport: an update. Sports Medicine, 44(12), 1645-1658. https://doi.org/10.1007/s40279-014-0230-6

Winter, E. M., \& Maughan, R. J. (2009). Requirements for ethics approvals. Taylor \& Francis. https://doi.org/10.1080/02640410903178344

\section{Acknowledgments}

The authors would like to thank the participants for their invaluable contribution in this study. 